\title{
Kontribusi Bekal Makanan dan Total Energi terhadap Status Gizi pada Anak Sekolah Dasar
}

\section{The Contribution of Packed Lunch and Energy Total to Nutritional Status in Elementary School Students}

Desy Dwi Anugraheni*, Bibit Mulyana ${ }^{1}$, Farapti²

\begin{abstract}
ABSTRAK
Latar Belakang: Anak usia sekolah merupakan usia kritis yang kebutuhan energi dan zat gizinya harus tercukupi, karena pada usia ini anak mengalami tumbuh dan berkembang. Anak cenderung lebih banyak menghabiskan waktu seharian penuh di sekolah karena aturan fullday, sehingga waktu makan siang mereka juga terlewati disekolah. Oleh karena itu, diperlukan bekal makanan yang berkualitas untuk memenuhi kebutuhan makan siang di sekolah.

Tujuan: Tujuan penelitian ini adalah untuk menganalisis hubungan kontribusi bekal makanan dan total energi dengan status gizi (IMT/U) pada anak sekolah dasar di SD Muhammadiyah 4 Surabaya.

Metode: Penelitian cross sectional dilakukan di SD Muhammadiyah 4 Surabaya pada bulan April-Mei 2018. Sampel pada penelitian ini adalah siswa kelas 4 dan 5 dengan jumlah 108 siswa dan dipilih secara simple random sampling. Pengumpulan data penelitian dilakukan dengan wawancara menggunakan kuesioner dan recall selama 2 hari. Analisis hubungan yang digunakan adalah korelasi Pearson.

Hasil: Rata-rata total energi siswa adalah 1614,2 kkal dengan kontribusi bekal makanan sebesar 558,7 kkal atau 27,8\% dari total kebutuhan energi. Selain itu, penelitian ini menunjukkan bahwa sebanyak 45,3\% siswa memiliki status gizi lebih. Terdapat hubungan yang signifikan antara kontribusi bekal makanan $(p<0,001)$ dan total energi $(p<0,001)$ dengan status gizi pada anak sekolah dasar.

Kesimpulan: Status gizi anak sekolah dasar dipengaruhi oleh kontribusi bekal makanan dan total energi sehari. Sehingga semakin tinggi kontribusi bekal makanan dan total energi sehari maka status gizi anak juga semakin tinggi.
\end{abstract}

Kata Kunci: kontribusi bekal makanan, total energi, status gizi

\section{ABSTRACT}

Background: School-age children are critical period which are energy and nutritional needs must be adequate, because they are on growing and developing period. Children tend to spend more time at school because of fullday school rule, so they would skip lunch at school. Therefore, the quality of packed lunch is needed to fulfill the lunch's children at school.

Objectives: This study aimed to analyze the relationship of packed lunch contribution and energy total with nutritional status (BMI/A) in elementary school students at SD Muhammadiyah 4 Surabaya.

Methods: The cross sectional study was conducted between April-Mei 2018 in Muhammadiyah 4 elementary school Surabaya. The sample of the study were a group of fourth and fifth grade with total of 108 student that chosen by simpel random sampling. The data collected through interview using a questionnaire and recall for 2 days. Person corelation was used to analyze statistically.

Results: The average of students energy total is $1614.2 \mathrm{kcal}$ which packed lunch contributed $558.7 \mathrm{kcal}$ or $27.8 \%$ total energy requirement. Therefore, this study showed $45.3 \%$ students were overweight and obesity. There was a significant association between packed lunch contribution $(p<0.001)$ and energy total $(p<0.001)$ with nutritional status among elementary school children.

Conclusions: The nutritional status of elementary children is influenced by the contribution of packed lunch and daily energy total. Therefore higher contribution of packed lunch and daily energy total absoutely the children's nutritional status are also higher.

Keywords: contribution of packed lunch, energy total, nutritional status 


\author{
*Koresponden: \\ desyanugraheni@gmail.com \\ ${ }^{1}$ Universitas Muhammadiyah Gresik, Jl. Sumatera No.101, Gn. Malang, \\ Randuagung, $61121 \mathrm{Kec}$. Gresik, Kabupaten Gresik, Jawa Timur, Indonesia \\ ${ }^{2}$ Departemen Gizi Kesehatan, Fakultas Kesehatan Masyarakat, Universitas Airlangga \\ Kampus C Mulyorejo, 60115 Surabaya, Jawa Timur, Indonesia
}

\section{PENDAHULUAN}

Status gizi merupakan suatu keadaan tubuh yang diakibatkan oleh konsumsi makanan dan penggunaan zat-zat gizinya. Apabila tubuh seseorang memperoleh zat-zat gizi yang cukup dan digunakan secara efisien maka status gizi orang tersebut dapat dikatakan sebagai status gizi optimal atau normal. Selain itu, status gizi optimal atau normal dapat terjadi karena seimbangnya antara konsumsi makanan dengan pengeluarannya ${ }^{1}$. Akan tetapi apabila keadaan tersebut tidak dapat terjadi, maka akan menyebabkan masalah gizi seperti gizi kurang maupun gizi lebih. Salah satu kelompok umur yang sangat rentan mengalami permasalahan gizi dan kesehatan adalah anak usia sekolah, hal tersebut dikarenakan pada usia sekolah terjadi perkembangan tulang, gigi, otot, darah sehingga mereka membutuhkan lebih banyak asupan gizi dibandingkan kelompok dewasa².

Data World Health Organization (WHO) tahun 2018 menunjukkan bahwa, di dunia prevalensi overweight tahun 2017 yaitu sebesar 5,6\% ${ }^{3}$. Prevalensi tersebut mengalami peningkatan apabila dibandingkan dengan prevalensi tahun 2010 yaitu 5,3\%. Berdasarkan tren beberapa tahun, Indonesia memiliki prevalensi gizi lebih yang meningkat. Berdasarkan Balitbangkes tahun 2010 menyunjukkan bahwa prevalensi gizi lebih adalah 9,2\% sedangkan pada tahun 2013 meningkat sebesar $18,8 \%{ }^{4}$. Sedangkan provinsi Jawa Timur menduduki posisi kedua diantara 15 provinsi lain dengan prevalensi sangat gemuk diatas prevalensi Indonesia ${ }^{4}$. Penelitian yang dilakukan oleh Qamariyah (2017) menunjukkan prevalensi gizi lebih sebesar 30,3\%, dimana apabila dibandingkan dengan prevalensi di Surabaya $(3,58 \%)$ dapat dikatakan lebih tinggi ${ }^{5,6}$.

Anak sekolah dasar dengan status gizi yang kurang dapat mengakibatkan beberapa permasalahan antara lain berkurangnya daya tangkap, terjadi penurunan konsentrasi belajar, pertumbuhan fisik tidak optimal, memiliki postur tubuh yang cenderung pendek, serta tidak aktif dalam bergerak ${ }^{7}$. Begitu pula dengan anak yang memiliki status gizi overweight dan obesitas, apabila anak mengalami masalah gizi ini di usia muda maka akan cenderung berlanjut diusia dewasa dimana masalah ini memiliki korelasi terhadap terjadinya penyakit metabolik dan degenaratif yang kini banyak diderita oleh masyarakat seperti penyakit kardiovaskuler, hipertensi, diabetes mellitus, dan berbagai jenis kanker ${ }^{8,9}$. Selain itu overweight dan obesitas juga dapat menurunkan produktivitas dan kualitas hidup seseorang, hal tersebut berkaitan dengan peningkatan beban biaya medis, psikologis, dan biaya sosial ${ }^{10}$.
Pendidikan formal di Indonesia terus mengalami perubahan salah satunya perubahannya adalah hari efektif belajar. Anak usia sekolah dasar pada umumnya menghabiskan sepertiga waktunya di sekolah, sehingga kegiatan makan siang tidak dapat dilakukan di rumah melainkan di sekolah. Makan siang disekolah harus memenuhi gizi seimbang baik dari segi jumlahnya maupun keragaman makanannya, sehingga kualitas makanan yang dikonsumsi anak dapat terjamin dengan membawa bekal tersebut ${ }^{11}$. Keuntungan membawa bekal makanan dari rumah adalah makanan yang dikonsumsi anak lebih mudah dipantau kandungan gizinya, higiene dan kebersihannya serta dapat menghindari kebiasaan jajan yang kurang sehat di sekolah $^{12}$.

Makan siang yang dilakukan di sekolah memiliki kontribusi energi pada total konsumsi energi sehari dan akan berdampak pada status gizi anak. Rekomendasi yang dianjurkan untuk makan siang adalah memenuhi $1 / 3$ dari total kebutuhan sehari ${ }^{13,14,8}$. Akan tetapi penelitian terdahulu menyebutkan bahwa bekal makanan anak belum memenuhi rekomendasi dari $1 / 3$ total kebutuhan sehari. Penelitian tersebut menyebutkan bahwa bekal makan lebih sedikit mengandung kalsium, zat besi, dan serat ${ }^{13}$. Selain itu pada bekal makanan juga lebih sedikit mengandung protein dan vitamin $\mathrm{C}^{15}$.

Berdasarkan penjelasan diatas maka penting untuk melakukan penelitian terkait dengan status gizi anak sekolah dasar. Penelitian ini memiliki tujuan untuk menganalisis hubungan antara kontribusi bekal makanan dan total energi dengan status gizi anak sekolah dasar di SD Muhammadiyah 4 Surabaya.

\section{METODE}

Penelitian ini merupakan jenis observasional dengan desain cross sectional. Tempat pelaksanaan penelitian ini adalah di SD Muhammadiyah 4 Surabaya dan dilakukan pada bulan April-Mei 2018. Sampel pada penelitian ini adalah sebanyak 108 siswa dengan teknik pengambilan simple random sampling. Variabel penelitian ini meliputi kontribusi energi bekal makanan, total energi dalam sehari, dan status gizi berdasarkan IMT/U.

Metode wawancara digunakan untuk mengetahui data karakteristik responden (usia, jenis kelamin, uang saku) sedangakan metode recall $2 \times 24$ jam dilakukan untuk mengetahui asupan makanan responden. Pada penelitian ini metode recall dilakukan selama 2 hari dengan hari yang berbeda. Data status gizi diperoleh dengan penilaian antropometri indikator IMT/U. 
Tinggi badan responden diukur menggunakan stadiometer merk SECA dengan tingkat ketelitian $0,1 \mathrm{~cm}$ sedangkan berat badan diukur menggunakan timbangan digital merk GEA dengan tingkat ketelitian $0,1 \mathrm{~kg}$. Berdasarkan indeks IMT/U dengan indikator Z-Score, pengkategorian status gizi sebagai berikut obesitas ( $>2$ SD); overweight/gemuk (>1 SD - 2 SD); normal (-2 SD - 1 $\mathrm{SD})$; kurus (-3 SD - <-2SD); sangat kurus $(<-3 \mathrm{SD})^{16}$.

Uji korelasi pearson digunakan pada penelitian ini untuk analisa data tentang hubungan antara kontribusi bekal makanan dan total energi dengan status gizi pada anak sekolah dasar. Tingkat signifikansi yang digunakan pada penelitian ini adalah $p<0,05$. Komisi Etik Penelitian Kesehatan Masyarakat Universitas Airlangga telah memberikan sertifikat lulus kaji etik pada penelitian ini dengan nomor 408-KEPK.

\section{HASIL DAN PEMBAHASAN}

Penelitian ini meneliti tentang karakteristik responden berdasarkan jenis kelamin, umur, besar uang saku dan status gizi. Berdasarkan Tabel 1 menunjukkan bahwa sebanyak $52,8 \%$ responden berjenis kelamin perempuan. Umur responden sebagian besar berada pada kelompok umur 10 tahun yaitu sebesar 48,1\%. Sebanyak $64,8 \%$ responden memiliki uang saku dibawah rata-rata yaitu dibawah $\mathrm{Rp} 12.000$.

Pada usia anak sekolah yaitu 6-12 tahun terjadi masa pertumbuhan dan perkembangan yang lebih stabil jika dibandingkan dengan bayi dan balita. Keadaan tersebut seperti pertumbuhan fisik yang terlihat seperti lambat akan tetapi pada perkembangan motorik, kognitif, serta emosi sosial sudah mulai matang. Sehingga keadaan tersebut dapat menimbulkan beberapa masalah gizi salah satunya yaitu gizi lebih ${ }^{17}$.

Pada Tabel 2 diketahui bahwa sebanyak 47,2\% responden memiliki status gizi normal, akan tetapi prevalensi gizi lebih juga meunjukkan presentase yang cukup tinggi apabila dibandingkan dengan prevalensi Nasional yaitu sebanyak 45,3\% dimana $22,2 \%$ kategori gemuk dan 23,1\% kategori obesitas, sedangkan prevalensi gizi lebih Nasional menunjukkan presentase $18,8 \%$

Tabel 1. Karakteristik Responden

\begin{tabular}{ccc}
\hline Karakteristik & $\begin{array}{c}\text { Jumlah } \\
\text { (n=108) }\end{array}$ & Presentase (\%) \\
\hline $\begin{array}{ccc}\text { Jenis Kelamin } \\
\text { Laki-laki }\end{array}$ & 51 & 47,2 \\
$\quad \begin{array}{l}\text { Perempuan } \\
\text { Umur (tahun) }\end{array}$ & 57 & 52,8 \\
9 & & \\
10 & 20 & 18,5 \\
11 & 52 & 48,1 \\
12 & 33 & 30,6 \\
Uang Saku & 3 & 2,8 \\
< Rata-rata* & & \\
$\geq$ Rata-rata* & 70 & 64,8 \\
\hline
\end{tabular}

*Rata-rata $=\mathrm{Rp} 12.000$
Tabel 2. Status Gizi Responden

\begin{tabular}{ccc}
\hline $\begin{array}{c}\text { Karakteristik } \\
\text { Responden }\end{array}$ & $\begin{array}{c}\text { Jumlah } \\
(\mathbf{n = 1 0 8 )}\end{array}$ & Presentase (\%) \\
\hline Status Gizi & & \\
Sangat Kurus & 1 & 0,9 \\
Kurus & 7 & 6,5 \\
Normal & 51 & 47,2 \\
Gemuk & 24 & 22,2 \\
Obesitas & 23 & 23,1 \\
\hline
\end{tabular}

dimana 10,8\% kategori gemuk dan 8,8\% kategori obesitas $^{4}$. Berdasarkan hasil recall $2 \times 24$ jam disebutkan bahwa salah satu yang dapat menjadi penyebab terjadinya gizi lebih pada siswa adalah asupan lemak yang berlebih. Berlebihnya asupan lemak pada siswa karena siswa mengonsumsi makanan cepat saji dan gorengan seperti pizza, burger, ayam goreng, ikan goreng, tempe goreng, tahu goreng, telur goreng.

Makanan yang mengandung lemak memberikan rasa yang renyah dan kalori yang tinggi apabila makanan tersebut digoreng. Penelitian terdahulu menyebutkan bahwa siswa dengan asupan lemak yang berlebih memiliki risiko 4,4 kali lebih besar untuk mengalami obesitas apabila dibandingkan dengan siswa yang memiliki asupan lemak yang rendah. Keadaan ini memberikan makna bahwa asupan lemak yang berlebih dapat berpengaruh terhadap jaringan lemak ${ }^{18,19}$.

Rata-rata asupan energi bekal pada siswa SD Muhammadiyah 4 Surabaya adalah 558,7 kkal/hari. Rata-rata tersebut lebih tinggi apabila dibandingkan dengan penelitian sebelumnya yang dilakukan oleh Romo_Palafox, et al tahun 2017 menunjukkan bahwa rata-rata asupan energi pada bekal sebesar 374,4 kkal20. Makan siang yang seimbang harus menyediakan tidak lebih dari $1 / 3$ dari kebutuhan gizi harian ${ }^{8,14}$. Penelitian ini menunjukkan bahwa rata-rata asupan energi dari bekal dapat menyumbang energi dalam sehari sebesar $27,9 \%$.

Kontribusi energi bekal makanan tersebut apabila dibandingkan dengan anjuran 1/3 AKG masih dapat dikategorikan kurang. Berdasarkan hasil recall 2x24 jam menunjukkan bahwa jenis bekal yang dikonsumsi oleh siswa sebagian besar adalah makanan pokok dan lauk hewani, sedangkan sayur dan buah hanya sedikit siswa yang mengonsumsinya. Kurangnya asupan sayur dan buah dapat menjadi salah satu faktor penyebab terjadinya gizi lebih pada anak, hal tersebut sesuai dengan penelitian terdahulu yaitu anak yang tidak mengonsumsi sayur dan buah lebih berisiko 1,5 kali untuk mengalami obesitas apabila dibandingkan dengan anak yang mengonsumsi sayur dan buah.

Konsumsi serat yang cukup dapat mengurangi asupan lemak sehingga hal tersebut dapat mencegah terjadinya obesitas ${ }^{21}$. Berdasarkan hasil uji korelasi menggunakan uji pearson menunjukkan bahwa kontribusi bekal makanan dengan status gizi anak usia sekolah memiliki hubungan yang signifikan dengan nilai $p<0,001$. Terdapatnya hubungan pada penelitian ini karena ada beberapa responden yang memiliki bekal dengan porsi makanan yang cukup bahkan berlebih seperti makanan sumber lauk pauk, sehingga dapat mempengaruhi hasil pada penelitian ini. 
Tabel 3. Rata-rata dan Uji Korelasi dengan Status Gizi

\begin{tabular}{lcc}
\hline \multicolumn{1}{c}{ Variabel } & Rata-rata \pm SD & p-value \\
\hline Total Energi Sehari (kkal) & $1614,2 \pm 265,3$ & $<0,001$ \\
Total Energi Bekal Makanan (kkal) & $558,7 \pm 68,1$ & \\
Kontribusi Energi Bekal Makanan (\%) & $27,8 \pm 3,7$ & $<0,001$ \\
\hline
\end{tabular}

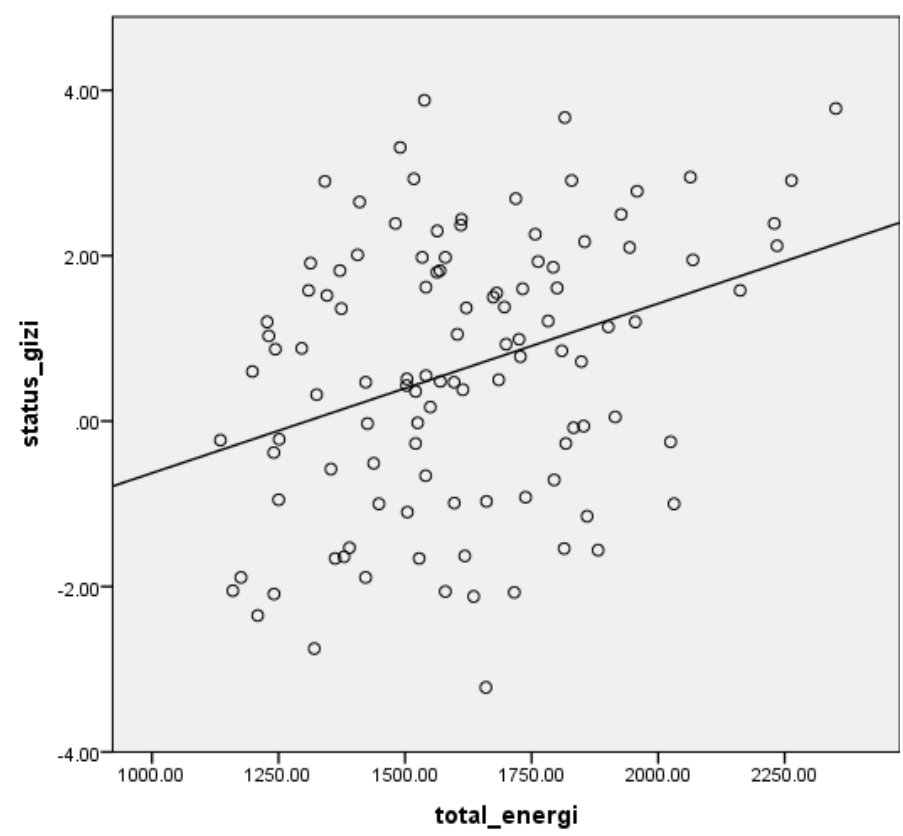

Gambar 1. Scatter plot Total Energi dengan Status Gizi

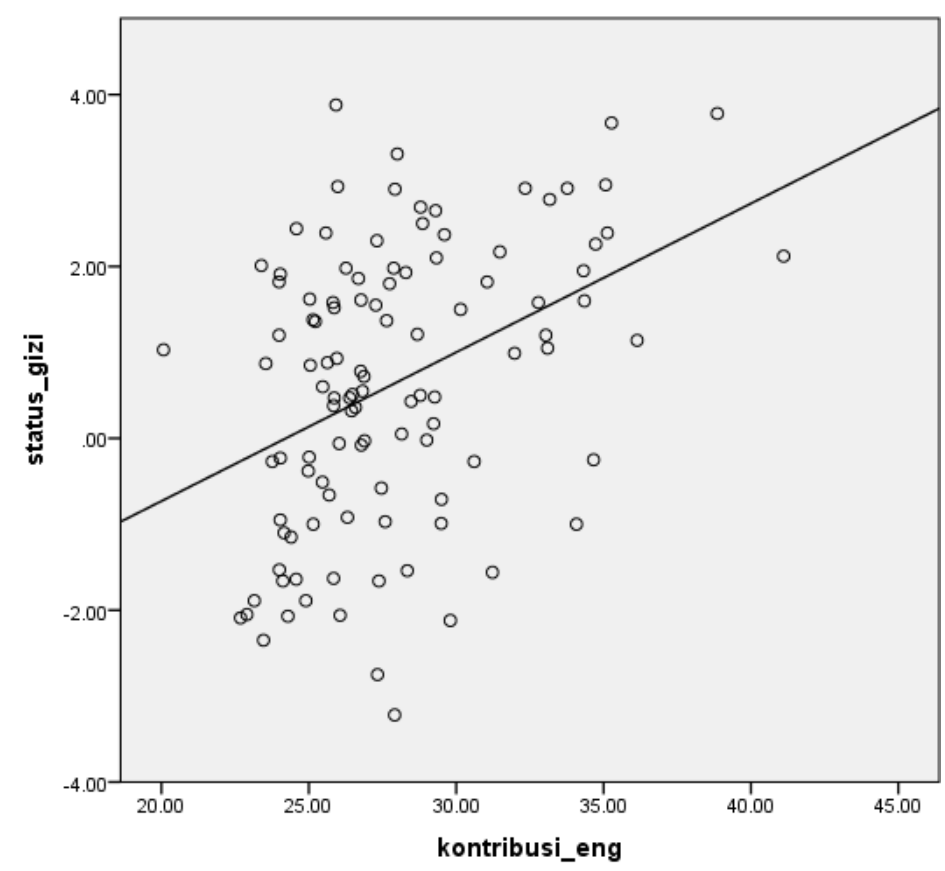

Gambar 2. Scatter plot Kontribusi Energi Bekal Makanan dengan Status Gizi

Kontribusi energi dan zat gizi makro harus tercukupi dengan baik karena dapat berfungsi untuk menunjang pertumbuhan serta perkembangan dan melakukan aktivitas fisik ${ }^{22}$. Apabila kontribusi tidak tercukupi dengan baik, khususnya energi dan protein maka akan berdampak pada status gizi anak yang dapat mengakibatkan tubuh menjadi lesu dan kurang bergairah sehingga akan berdampak pada aktivitas fisik ${ }^{1}$. 
Hasil penelitian menunjukkan rata-rata asupan energi siswa sebesar 1614,2 kkal/hari. Berdasarkan Balitbangkes tahun 2010 menunjukkan bahwa rata-rata asupan energi penduduk Indonesia adalah 1506 kkal/hari untuk anak umur 7-9 tahun, sedangkan pada anak laki-laki umur 10-12 tahun adalah $1628 \mathrm{kkal} / \mathrm{hari}$ dan pada anak perempuan adalah sebesar 1600

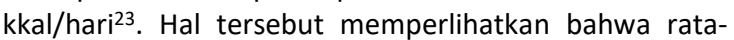
rata asupan energi pada anak umur 10-12 tahun tidak memiliki perbedaan yang jauh, sedangkan pada anak umur 7-9 tahun memiliki rata-rata asupan energi yang lebih tinggi.

Sedangkan apabila dibandingkan dengan angka kecukupan gizi, baik pada siswa berumur 7-9 tahun dan 10-12 tahun dapat dikatakan masih kurang, karena kecukupan energi pada anak umur 7-9 tahun adalah 1850 kkal dan pada anak umur 10-12 tahun sebesar 2000 kkal untuk anak perempuan dan 2100 kkal untuk anak laki-laki ${ }^{24}$. Berdasarkan ujii korelasi menggunakan uji pearson menyatakan bahwa antara asupan total energi dengan status gizi menunjukkan hubungan yang signifikan dengan nilai $p=0,000$. Penelitian ini serupa dengan penelitian terdahulu yang dilakukan di Makassar, dimana penelitian tersebut menunjukkan hubungan yang bermakna antara asupan energi dengan status gizi pada anak sekolah dasar di wilayah pesisir 25 .

Selain itu, penelitian yang dilakukan di Manado pada anak sekolah dasar juga menunjukkan bahwa asupan energi dengan kejadian obesitas memiliki hubungan yang signifikan, hal tersebut berarti bahwa salah satu yang dapat meningkatkan risiko gizi lebih adalah asupan energi yang berlebih ${ }^{26}$. Penelitian tersebut sejalan dengan teori yang menyebutkan bahwa salah satu yang mempengaruhi status gizi seseorang adalah konsumsi makanan ${ }^{1}$. Status gizi normal pada seseorang dapat terjadi karena zat-zat gizi yang terdapat didalam tubuh dapat digunakan secara baik dan efisien, sehingga dapat membantu proses pertumbuhan dan perkembangan ${ }^{1}$. Selain itu konsumsi makanan juga dapat mempengaruhi perkembangan otak, apabila konsumsi makanan tidak mencukupi kebutuhan gizi yang dianjurkan dalam waktu yang lama maka dapat menyebabkan perubahan metabolisme otak ${ }^{27}$. Hal ini selaras dengan penelitian yang dilakukan di Padangpanjang yang menyebutkan bahwa status gizi anak sekolah dasar berhubungan dengan prestasi belajar ${ }^{28}$.

Selain itu fungsi energi adalah untuk melakukan aktivitas fisik dan fungsional dasar tubuh. Apabila tubuh tidak menggunakan energi untuk melakukan aktivitas fisik maka tubuh akan menyimpan energi tersebut menjadi lemak dalam tubuh. Apabila makin banyak energi yang dikonsumsi dari kebutuhan, maka semakin tinggi pula simpanan energi dalam tubuh yang dapat mengakibatkan peningkatan berat badan pada seseorang dan dapat mempengaruhi status gizi. Begitupun berlaku sebaliknya, dimana semakin sedikit asupan energi yang dikonsumsi dari kebutuhan maka simpanan energi juga akan menurun dan hal tersebut dapat menyebabkan penurunan berat badan ${ }^{29}$.

\section{KESIMPULAN}

Kontribusi bekal makanan dan total energi sehari berhubungan dengan status gizi pada anak sekolah dasar di SD Muhammadiyah 4 Surabaya. Berdasarkan penelitian ini, semakin tinggi kontribusi bekal makanan dan total energi dalam sehari maka status gizi anak juga akan semakin tinggi.

\section{ACKNOWLEDGEMENT}

Ucapan terimakasih peneliti sampaikan kepada seluruh responden penelitian, seluruh guru dan staff di SD Muhammadiyah 4 Surabaya, serta teman-teman yang telah membantu kelancaran penelitian ini.

\section{REFERENSI}

1. Almatsier, S. Prinsip Dasar Ilmu Gizi. (PT Gramedia Pustaka Utama, 2009).

2. RSCM Persagi. Penuntun Diit Anak. (Gramedia, 2003).

3. UNICEF, WHO \& The World Bank. Levels \& Trends in Cild Malnutrition. (2018).

4. Balitbangkes. Riset Kesehatan Dasar Tahun 2013. (Kementrian Kesehatan RI, 2013).

5. Qamariyah, B. \& Nindya, T. S. Hubungan Antara Asupan Energi, Zat Gizi Makro dan Total Energy Expenditure dengan Status Gizi Anak Sekolah Dasar. Amerta Nutr. 2, 59-65 (2018).

6. Dinas Kesehatan Kota Surabaya. Profil Kesehatan Tahun 2016 Pemerintah Kota Surabaya. (2017).

7. Kandala, N.-B., Madungu, T. P., Emina, J. B., Nzita, K. P. \& Cappuccio, F. P. Malnutrition Among Children Under The Age of Five in The Democratic Republic of Congo (DRC): Does Geographic Location Matter? BMC Public Health 11, 1-15 (2011).

8. Wilkinson, J. Comparison of Packed School Lunches of Boys and Girls in Primary Schools in East London. (2015).

9. Permatasari, I. R. I., Mayulu, N. \& Hamel, R. Analisa Riwayat Orang Tua Sebagai Faktor Resiko Obesitas Pada Anak SD Di Kota Manado. J. KEPERAWATAN 1, 1-7 (2018).

10. Kemenkes RI. Pedoman Pencegahan dan Penanggulangan Kegemukan dan Obesitas pada Anak Sekolah. (Direktorat Jenderal Bina Gizi dan Kesehatan Ibu dan Anak, 2012).

11. Kemenkes RI. Pedoman Gizi Seimbang. (Direktur Jenderal Bina Gizi dan Kesehatan Ibu dan Anak, 2014).

12. Ayuniyah, Q., Indriani, Y. \& Rangga, K. K. Ketersediaan dan Perilaku Konsumsi Maknan Jajanan Olahan Siswa Sekolah Dasar di Bandar Lampung. J. IImu-IImu Agribisnis 3, 409-418 (2015).

13. Johnson, C. M., Bednar, C., Kwon, J. \& Gustof, A. Comparison of Nitrient Content and Cost HomePacked Lunches to Reimbursable School Lunch Nutrient Standards and Price. Sch. Nutr. Assoc. 33, 1-8 (2009). 
14. Jeffery, R. W. et al. Effects of Portion Size on Chronic Energy Intake. Int. J. Behav. Nutr. Phys. Act. 4, 1-5 (2007).

15. Griffin, T. L. \& Barker, M. E. Packed Lunches for Primary-School Children: A Qualitative Study of Parents' Views. Proc. Nutr. Soc. 67, 218 (2008).

16. Kemenkes RI. Keputusan Menteri Kesehatan Republik Indonesia Tentang Standar Antropometri Penilaian Status Gizi Anak. (2011).

17. Brown, J. Dietary Reference Intakes (DR/s): Recommended Intakes for Individuals, Vitamins Food and Nutrition Board, Institute of Medicine, National Academies. Fluoride (2011). doi:10.1111/j.1753-4887.2004.tb00011.x

18. Mustika, P. A. \& Muniroh, L. Hubungan Pola Konsumsi dan Aktivitas Fisik dengan Gizi Lebih Pada Siswa Sekolah Menegah Atas (SMA). Media Gizi Indones. 2, 1518-1527 (2012).

19. Kharismawati, R. \& Sunarto. Hubungan Tingkat Asupan Energi, Protein, Lemak, Karbohidrat, dan Serat dengan Status Obesitas Pada Siswa SD. Univ. Diponegoro (2010).

20. Romo-Palafox, M. J. et al. Adequacy of ParentPacked Lunches and Preschooler's Consumption Compared to Dietary Reference Intake Recommendations. J. Am. Coll. Nutr. 36, 169176 (2017).

21. Sartika, R. A. D. Faktor - faktor Risiko Pada Anak 5-15 Tahun Di Indonesia. MAKARA, Kesehat. 15,
37-43 (2011).

22. Pietroiusti, A. et al. Incidence of metabolic syndrome among night-shift healthcare workers. Occup. Environ. Med. 67, 54-57 (2010).

23. Balitbangkes. Riset Kesehatan Dasar Tahun 2010. (Kementrian Kesehataan RI, 2010).

24. Kemenkes RI. Peraturan Menteri Kesehatan Republik Indonesia Nomor 75 Tahun 2013 Tentang Angka Kecukupan Gizi Yang Dianjurkan Bagi Bangsa Indonesia. (Kementrian Kesehatan $\mathrm{RI}, 2013$ ).

25. Yulni. Hubungan asupan zat gizi makro dengan status gizi pada anak sekolah dasar di wilayah pesisir kota Makassar. Media Kesehat. Masy. Indones. 9, 205-211 (2013).

26. Yamin, B., Mayulu, N. \& Rottie, J. Hubungan Asupan Energi dengan Kejadian Obesitas pada Siswa Sekolah Dasar di Kota Manado. Ejournal Keperawatan 1, 1-7 (2013).

27. Cakrawati, D. Bahan Pangan, Gizi, dan Kesehatan. (Alfabeta, 2012).

28. Sa'adah, R. H., Herman, R. B. \& Sastri, S. Hubungan Status Gizi dengan Prestasi Belajar Siswa Sekolah Dasar Negeri 01 guguk Malintang Kota Padangpanjang. J. Kesehat. Andalas 3, 460465 (2014).

29. Whitney, E. \& Rolfes, S. Understanding Nutrition. (Thomson Higher Education, 2008). 